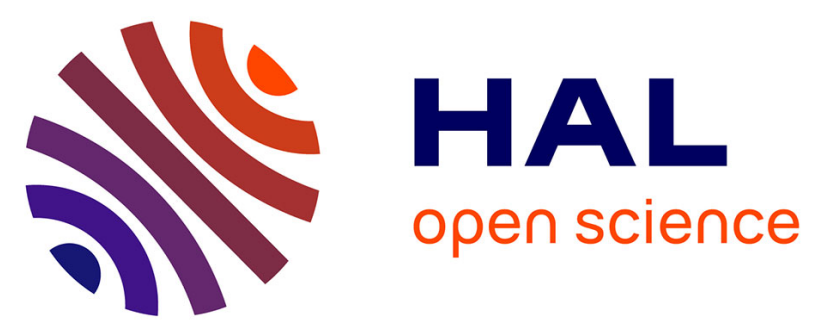

\title{
Carbohydrate remobilization from storage root to leaves after a stress release in sugar beet (Beta vulgaris L.): experimental and modelling approache
}

\author{
Marie Launay, Anne-Isabelle Graux, Nadine N. Brisson, Martine Guerif
}

\section{To cite this version:}

Marie Launay, Anne-Isabelle Graux, Nadine N. Brisson, Martine Guerif. Carbohydrate remobilization from storage root to leaves after a stress release in sugar beet (Beta vulgaris L.): experimental and modelling approache. Journal of Agricultural Science, 2009, 147 (6), pp.669-682. 10.1017/S0021859609990116 . hal-02662067

\section{HAL Id: hal-02662067 https://hal.inrae.fr/hal-02662067}

Submitted on 30 May 2020

HAL is a multi-disciplinary open access archive for the deposit and dissemination of scientific research documents, whether they are published or not. The documents may come from teaching and research institutions in France or abroad, or from public or private research centers.
L'archive ouverte pluridisciplinaire HAL, est destinée au dépôt et à la diffusion de documents scientifiques de niveau recherche, publiés ou non, émanant des établissements d'enseignement et de recherche français ou étrangers, des laboratoires publics ou privés. 


\title{
Carbohydrate remobilization from storage root to leaves after a stress release in sugar beet (Beta vulgaris $\mathrm{L}$.$) :$ experimental and modelling approaches
}

\author{
M. LAUNAY ${ }^{1 *}$, A.-I. GRAUX ${ }^{2}$, N. BRISSON ${ }^{1}$ AND M. GUERIF ${ }^{3}$ \\ ${ }^{1}$ Unite Agroclim, Institut National de Recherche Agronomique (INRA), Site Agroparc, \\ 84914 Avignon Cedex 9, France \\ ${ }^{2}$ Unite UNREP, INRA, Site de Crouël, 234 Avenue du Brézet, 63100 Clermont-Ferrand, France \\ ${ }^{3}$ Unite EMMAH, INRA, Site Agroparc, 84914 Avignon Cedex 9, France
}

(Revised MS received 30 March 2009; First published online 1 July 2009)

\begin{abstract}
SUMMARY
Carbohydrate remobilization from the sugar beet storage root to support leaf regrowth after release from water stress was demonstrated by experimental and modelling approaches. Experimental trials were carried out in northern France in 1994 and 1995 and in southern France in 2005, in conditions that involved a succession of soil moisture stresses and re-hydrations. Drought stress slowed leaf growth and the subsequent release of stress resulted in regrowth. A second trial showed that after total defoliation, sugar beet was able to produce new leaves. It was assumed that this leaf renewal, observed at drought stress release or after defoliation, relied on the possibility of remobilizing carbohydrates from storage roots to above-ground organs. This assumption was tested through a heuristic modelling approach, involving the STICS crop model and its existing sub-model on remobilization. The relevance of these formalizations for sugar beet was tested on the experimental data to validate the plant behaviour concerning remobilization. The model succeeded in reproducing leaf area index (LAI) dynamic trends and particularly leaf re-growth after drought stress release or defoliation, despite an over-estimation of the drought stress effect involving an inaccurate simulation of the changes in LAI. Nevertheless, the model's ability to forecast accurately above-ground and storage root dry weight, as well as trends in LAI dynamics, showed that the assumptions made about remobilization were able to explain sugar beet behaviour.
\end{abstract}

\section{INTRODUCTION}

Remobilization is the translocation of soluble organic molecules (water soluble carbohydrates (WSC), amino acids, soluble proteins, etc.) between plant organs, possibly after hydrolysis. Remobilized assimilates, or translocated reserves, differ from newly formed assimilates arising from photosynthesis: they mainly correspond to non-structural matter. The present paper will focus on carbon pools, though this process has also been studied for nitrogen pools (Vizoso et al. 2008; Dordas \& Sioulas 2009) and strong correlations exist between them. This process concerns all plants but is of particular importance

\footnotetext{
* To whom all correspondence should be addressed. Email: Marie.Launay@avignon.inra.fr
}

for crops, either for yield production or for ensuring plant survival during adverse conditions (winter, drought, etc.).

Remobilization has been thoroughly studied in relation to the filling process of harvested storage organs. Carbohydrate reserves accumulated before grain filling, and particularly before anthesis by cereal plants, are translocated from organs such as stems, roots or leaves to storage organs and contribute to grain yield (Papakosta \& Gagianas 1991; Tahir et al. 2005). In the case of perennial plants, both herbaceous and woody, a carbon reservoir built up at the end of the growing season, mainly located in the root system (Teng et al. 1999), is remobilized after winter to stimulate the onset of photosynthetic activity and vegetative growth in spring. Sugar beet, which is biennial, seems to behave like a perennial plant, using 
its root as a storage organ from which carbohydrates can be translocated to support vegetative regrowth. Indeed, remobilization has been suggested to explain sugar beet's good water use efficiency (Rubino et al. 1999) and adaptability to stress (Rossi et al. 2000), but this phenomenon has never been demonstrated. Owen \& Watson (1956) reported that small amounts of rainfall after prolonged drought caused rapid leaf growth in sugar beet and that these plants temporarily grew faster than irrigated ones that had never been submitted to severe water stress. Milford et al. (1985) showed that rainfall was able to slow leaf senescence of rainfed sugar beet crops, unlike irrigated crops. Perata et al. (2004) demonstrated by means of a field experiment coupled with a molecular probe that young sugar beet leaves behaved like sink tissues, whereas the root system acted as a source organ.

To demonstrate this remobilization process, many methods have been used: biomass balance, isotopic tracers, and more recently molecular biology. Defoliation or shoot excision were used in experiments on perennial crops to artificially induce remobilization (Gordon et al. 1986; Sakai \& Sakai 1998; El Omari et al. 2003). Molecular approaches are common, sometimes associated with isotopic methods, and they reveal hormonal regulation and proteolytic activity involved in carbohydrate storage and remobilization (Teng et al. 1999; Yang et al. 2004; Ebrahim 2005). Perata et al. (2004) showed that the expression of the sucrose transporter mRNA of sugar beet (BvSUT1) was restricted to fully expanded leaves and roots, excluding young growing leaves. In wellwatered and well-fertilized field conditions, the excessive leaf renewal probably resulted in competition between sink tissues (root and growing young leaves) and affected the sugar content in the root. As roots exhibit a noteworthy pattern of accumulation of BvSUT1, this result could support the reasonable hypothesis of a sucrose backflow to the production of new leaves, requiring the translocation of sucrose as an energy source from the root system.

Modelling approaches to remobilization have also been attempted in order to explain the carbon balance in various plant organs. More or less mechanistic submodels have been introduced into crop models such as those based on SUCROS (Spitters et al. 1989), e.g. SUCROS for sugar beet (Smit \& Struik 1995; Launay \& Guérif 2003), LINTUL for potatoes (Spitters \& Schapendonk 1990) and LINGRA for grasslands (Schapendonk et al. 1998), or APSIM (McCown et al. 1996) and STICS (Brisson et al. 2003) models. All these models assume that a storage pool is replenished when the photosynthetic supply exceeds the demand and possibly complements photosynthetic assimilate income later on. In the LINGRA model, this storage pool is remobilized during the first few days after defoliation. In APSIM-Nwheat (Probert et al. 1995), if grain growth demand during the grain filling period exceeds assimilate supply from photosynthesis, the difference can be supplied from assimilates stored prior to grain filling and remobilized. In SUCROS, as modified by Launay \& Guérif (2003), it is assumed that when water availability is increasing after a drought stress period, a fraction of dry matter is taken from the storage root and redirected to the above-ground organs. In STICS (Brisson et al. 2003, 2009), which is a sink model where organs have their own growth rate, reserves are calculated daily as the difference between the total biomass and the accumulated biomass of leaves and the structural part of stems and harvested organs. In the case of crops for which there is significant trophic competition between vegetative organs and harvested organs, because of an overlap between the vegetative phase and the reproductive phase, the trophic competition is considered as a driving force for production. A trophic stress index is then calculated, as a source/sink ratio, and reserves built up during the vegetative cycle contribute to this.

Whereas remobilization has been formalized in some models, it is often regarded as an adjustment component, rarely tested or used as interesting output. However, there are at least two modelling studies dealing with remobilization itself. Asseng \& van Herwaarden (2003) evaluated the APSIM-Nwheat model routine of remobilization using published data, while Schapendonk et al. (1998) used LINGRA to simulate regular defoliation due to grazing or cutting on a subset of the FAO database. The predictions agreed well with the experimental data: new leaves could only develop when carbohydrates were remobilized from the storage pool to compensate for low photosynthetic rates after defoliation and the storage pool was replenished when photosynthetic rates increased due to steadily increasing light interception.

The objective of the present paper is to demonstrate with experimental and modelling approaches the ability of sugar beet to remobilize carbohydrates from its storage root to support leaf re-growth after stress release. Firstly, experiments were carried out in northern and southern France aimed at showing sugar beet remobilization from a biomass balance point of view after drought stress release or defoliation. Secondly, the STICS model was used by testing the relevance of pre-existing remobilization sub-model for sugar beet.

\section{MATERIALS AND METHODS}

\section{Field trials}

\section{Experimental sites, soils and climates}

Two field trials were set up in northern France: in 1994 at Clermont $\left(49^{\circ} 40^{\prime} \mathrm{N}, 3^{\circ} 56^{\prime} \mathrm{E}\right)$ and in 1995 at Mons $\left(49^{\circ} 53^{\prime} \mathrm{N}, 3^{\circ} \mathrm{E}\right)$, and another in southern France 
Table 1. Soil characteristics for all field trials

\begin{tabular}{|c|c|c|c|}
\hline Soil characteristic & Clermont & Mons & Avignon \\
\hline \multicolumn{4}{|l|}{ Particle size ( $\%)$} \\
\hline Clay $(<2 \mu \mathrm{m})$ & $15 \cdot 0$ & $17 \cdot 0$ & $34 \cdot 1$ \\
\hline Silt $(2-20 \mu \mathrm{m})$ & $82 \cdot 0$ & $76 \cdot 0$ & $56 \cdot 9$ \\
\hline Sand $(20-2000 \mu \mathrm{m})$ & $3 \cdot 0$ & $7 \cdot 0$ & $9 \cdot 0$ \\
\hline $\mathrm{pH}$ & $7 \cdot 0$ & $7 \cdot 0$ & $8 \cdot 5$ \\
\hline $\begin{array}{l}\text { Maximum available water content }(\mathrm{mm} / \mathrm{mm} \text { soil) } \\
\text { (in } 0-1.8 \mathrm{~m} \text { soil layer as a maximum) }\end{array}$ & $0 \cdot 154$ & $0 \cdot 146$ & $0 \cdot 133$ \\
\hline $\begin{array}{l}\text { Organic nitrogen in the } 0-0.25 \mathrm{~m} \\
\text { soil layer }(\mathrm{g} / \mathrm{kg})\end{array}$ & $1 \cdot 1$ & $2 \cdot 1$ & $1 \cdot 3$ \\
\hline Bulk density in the $0-0.25 \mathrm{~m}$ soil layer & $1 \cdot 30$ & $1 \cdot 20$ & $1 \cdot 40$ \\
\hline
\end{tabular}

in 2005 (Avignon, $43^{\circ} 57^{\prime} \mathrm{N}, 4^{\circ} 49^{\prime} \mathrm{E}$ ). At Clermont and Mons, the soil was a $1.8 \mathrm{~m}$ deep silt loam (orthic luvisol, FAO classification; FAO 2006) and at Avignon it was a silt clay loam $(1.7 \mathrm{~m}$ deep, a fluvisol in the FAO classification). Soil information for all field trials is given in Table 1. The Avignon soil was particularly clayey ( $35 \%$ by volume), and the Mons soil had the highest organic nitrogen content, with $2 \cdot 1 \mathrm{~g} / \mathrm{kg}$ organic nitrogen in the $0-250 \mathrm{~mm}$ layer.

Meteorological data were obtained from weather stations located less than $0 \cdot 2 \mathrm{~km}$ from the field trials, except for global radiation in Clermont, which was measured less than $10 \mathrm{~km}$ from the field trial. Avignon had the driest climate $(496 \mathrm{~mm}$ of cumulative rainfall in 2005 as against $659 \mathrm{~mm}$ in Clermont in 1994 and $721 \mathrm{~mm}$ in Mons in 1995), with the highest temperatures (mean maximum temperature was $c .20^{\circ} \mathrm{C}$ in Avignon in $2005,16^{\circ} \mathrm{C}$ in Clermont in 1994 and $15^{\circ} \mathrm{C}$ in Mons in 1995) and the highest potential evapotranspiration (PET), averaging 7-8 $\mathrm{mm}$ /day during summer (Fig. 1). In Clermont and Mons, drought conditions occurred around $1200^{\circ} \mathrm{C}$ days after emergence $\left({ }^{\circ} \mathrm{Cdae}\right)$, when PET reached $5 \mathrm{~mm} /$ day.

\section{Plant management and treatments}

Sugar beet was sown on 25 April 2004 in Clermont, 10 April 1995 in Mons and 10 March 2005 in Avignon, the preceding crops being winter wheat in Clermont and Mons and oilseed rape in Avignon. Plant densities were 11 (Mons and Avignon) and 14 plants $/ \mathrm{m}^{2}$ (Clermont). Mineral nitrogen fertilizer was applied according to the soil $\mathrm{N}$ content before sowing in all experiments, in order to avoid nitrogen deficiency during crop growth (no nitrogen was applied in Avignon, whereas $150 \mathrm{~kg}$ was given, in one application, at both Mons and Clermont).

In Avignon, two different water regimes were applied. Before the drought period all plants were kept well watered (until 31 May 2005). Then, treatments and drought stress imposition were: Avignon continuous irrigation (CI), Avignon defoliated (DE) and
Avignon discontinuous irrigation (DI). Avignon CI and Avignon DE were both kept well watered and the treatment DE was defoliated on 11 August 2005. In Avignon DI, the irrigation was stopped to induce two strong drought stress periods: first, the irrigation was stopped for a period of 28 days, from 31 May to 28 June 2005, then irrigation was reinstated for a period of 13 days. Finally, irrigation was stopped again for 17 days, from 11 to 28 July 2005 .

\section{Experimental designs, sampling and analytical methods}

In Avignon, each main plot was 76 rows $\times 22 \mathrm{~m}$ and its location was chosen according to the irrigation equipment constraints and wind direction. Experimental plots (two rows $\times 1.5 \mathrm{~m}$ ) were laid out in a randomized design with three replicates. From mid-May to the end of August, plant measurements were made once or twice a week (24 measurement dates) and a late measurement date was added on 13 December. In Clermont and Mons, experimental plots (two rows $\times 2 \mathrm{~m}$ ) were laid out in a randomized block design with five or six replicates and plant measurements were made at 7-14-day intervals during the growing season. At every measurement date, 25 plants per replicate were dug up at Mons and Clermont and 10 at Avignon, and their total fresh weight and storage root fresh weight were measured. After planimeter leaf area index (LAI) measurement, the plant samples were dried at $70{ }^{\circ} \mathrm{C}$ for 2 days and total dry matter, green leaf (lamina and petiole) and storage root dry matter were determined as well as specific leaf area (SLA). Storage root sugar content was determined in Avignon with a polarimeter.

Soil water content was measured at 10-day intervals from mid-May to the end of August in Avignon, using a neutron probe. Aluminium access tubes were installed to a depth of $1.2 \mathrm{~m}$ at three positions in all treatment plots. To calibrate the neutron probe, two soil samples were collected from 0 to $0 \cdot 1,0 \cdot 1$ to $0 \cdot 2$ and 0.2 to $1.2 \mathrm{~m}$ layers, at locations $0.3 \mathrm{~m}$ from each access tube, to determine gravimetric soil moisture 
(a)
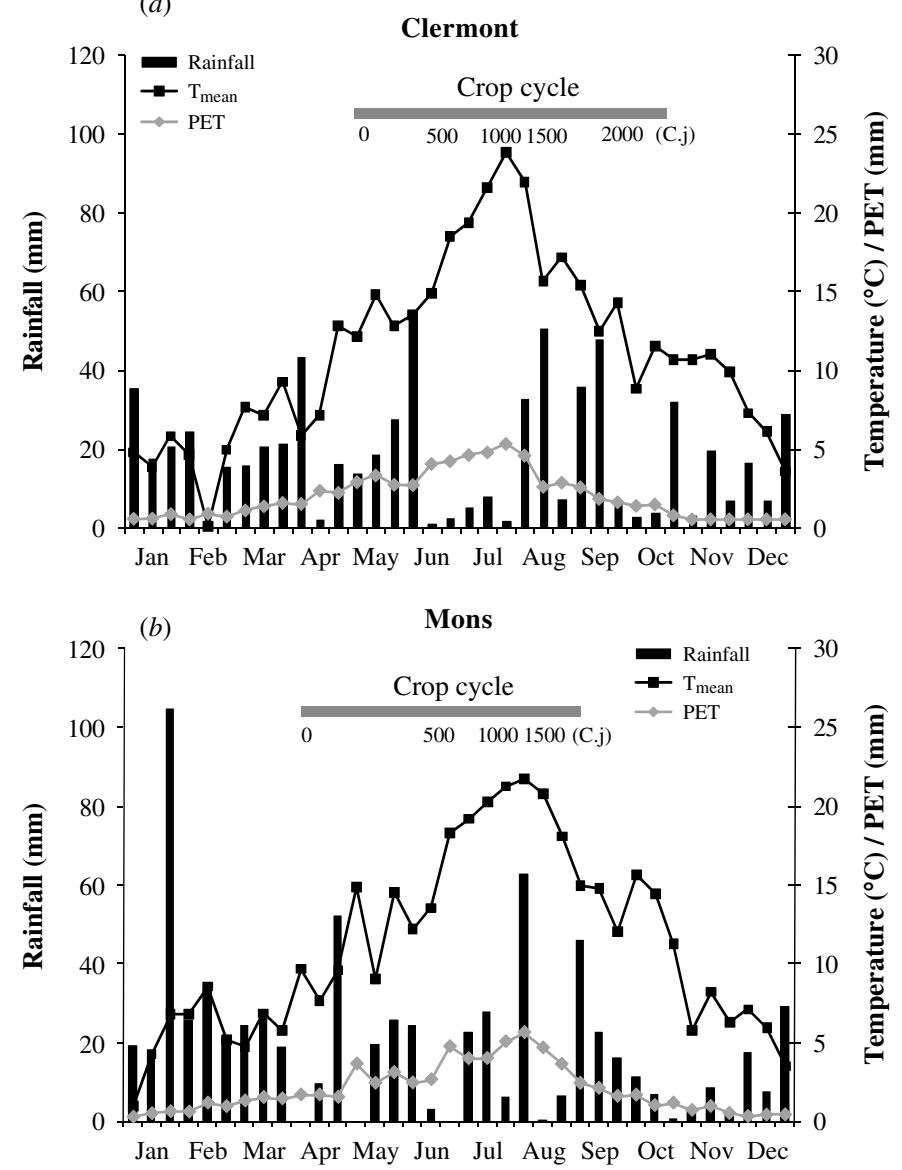

(c)

\section{Avignon}

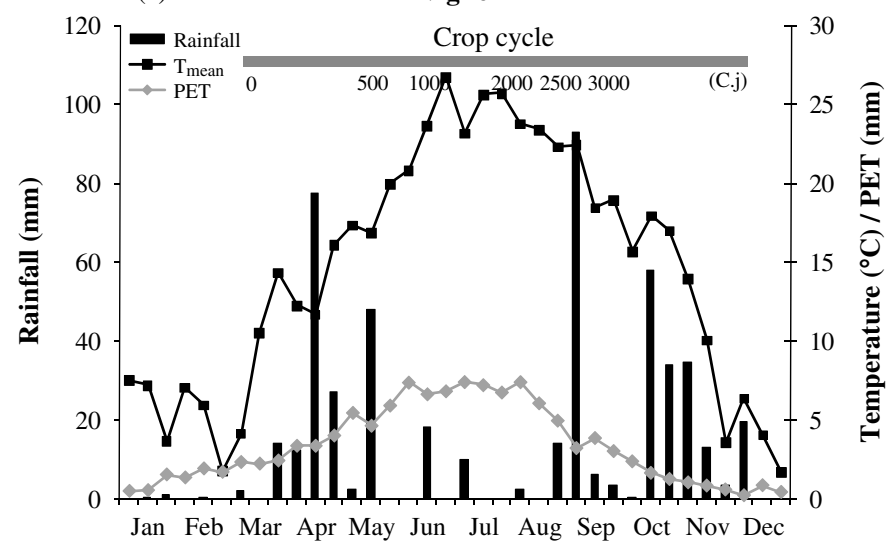

Fig. 1. Cumulative rainfall and averages of minimum and maximum air temperatures at $(a)$ Clermont, $(b)$ Mons and (c) Avignon $\left(T_{\min }\right.$ and $\left.T_{\max }\right)$ per decade. The thick grey line contains the crop cycle period.

contents, which were converted to volumetric values using bulk density values determined with a neutrongamma probe. During the Mons trial, the soil water content of eight soil layers $(0-1.6 \mathrm{~m})$ was measured at 7-day intervals, whereas it was measured three times in Clermont for six soil layers $(0-1 \cdot 2 \mathrm{~m})$, using a 
neutron probe at six positions in the experimental plot, with some additional gravimetric measurements for calibration. Experimental designs and sampling methods were described by Guérif et al. (1995) and Ceotto et al. (1999).

\section{Model}

The STICS growth model (Brisson et al. 2003, 2009) simulates the behaviour of the soil-crop system over one or several crop cycles, using a daily time step. Crops are modelled in terms of their total aboveground dry matter and $\mathrm{N}$ content, LAI, and the number and biomass (and $\mathrm{N}$ content) of harvested organs. The soil is divided into a number of horizontal layers, each of which is characterized in terms of its water, mineral $\mathrm{N}$ and organic $\mathrm{N}$ content. Soil and crop interact via the roots, which are defined by their density distribution in the soil profile. The main simulated processes are crop growth and development, water and $\mathrm{N}$ balance. Crop growth is driven by the plant's carbon metabolism: solar radiation interception by the foliage and its incorporation into above-ground dry matter that is directed to the harvested organs during the final phase of growth. Crop development is driven by thermal time and is used to make the leaf area evolve and to define the harvested organ filling phase. Potential water and/or $\mathrm{N}$ stress are taken into account through indices that can reduce leaf growth, root growth and biomass accumulation under wateror nutrient-limited growing conditions. The water stress index is calculated as the ratio between actual and potential transpiration and the $\mathrm{N}$ stress index corresponds to the $\mathrm{N}$ nutrition index (NNI) as defined by Lemaire \& Meynard (1997), calculated as the ratio of actual to critical plant $\mathrm{N}$ content.

\section{Trophic competition, leaf growth and harvested organ growth}

Simulation options allow significant trophic competition between vegetative organs and harvested organs. This trophic competition is taken into account through two trophic stress indices, varying between 0 and 1 , that reduce harvested organ daily growth rate (SOURCEPUITS) and leaf daily growth rate (SPLAI). SPLAI is calculated from the reference source/sink ratio SOURCEPUITS (Eqn 1)

$$
\text { SOURCEPUITS }=\frac{\text { DLTAMS }+ \text { REMOBILJ }}{\text { FPV }+ \text { FPFT }}
$$

where DLTAMS is the daily accumulated biomass from photosynthesis, REMOBILJ is the amount of biomass remobilized daily from the carbon pool reserves, FPV is the sink strength of vegetative organs, defined as the ratio between daily foliage growth and the minimum ratio of leaf surface area to shoot biomass and FPFT is the harvested organ sink strength related to a potential harvested organ growth.

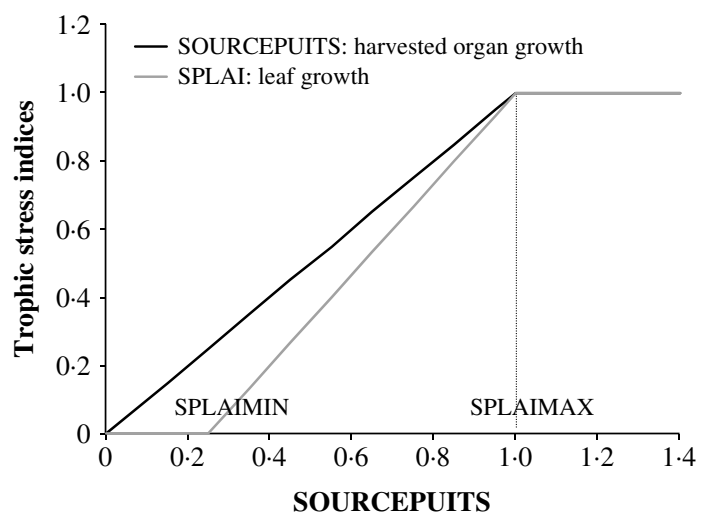

Fig. 2. Trophic stress indices (SOURCEPUITS and SPLAI) as a function of the source/sink ratio (SOURCEPUITS) using the parameters SPLAIMIN and SPLAIMAX. In this example, SPLAIMIN $=0 \cdot 25$ and SPLAIMAX $=1$ (from Brisson et al. 2009).

The SPLAI variable is defined by the SPLAIMIN and SPLAIMAX parameters (Fig. 2). The trophic stress indices cannot be considered as equivalent to coefficients of biomass allocation because they are not all applied to biomass. Consequently the relative position of the functions SOURCEPUITS and SPLAI do not indicate any priority between harvested organs and leaves: the priority needs to be calculated in terms of biomass and depends largely on the relative sink strengths of the organs.

The leaf area growth rate is driven by phasic development, temperature and stresses. A daily potential LAI growth rate is first calculated, related to the phenological key stages corresponding to emergence and to the end of leaf onset. This value is then multiplied by the effective crop temperature, the plant density multiplied by a density factor, assumed to represent inter-plant competition, and the water and nitrogen stress indices. Finally, it is multiplied by the trophic stress index SPLAI.

The harvested organ growth rate is driven by phasic development and trophic competition. It is calculated daily from the phenological stage corresponding to the beginning of harvested organ filling until physiological maturity when the harvested organs stop dry matter growth. This duration is defined by the DUREEFRUIT parameter, expressed as thermal time. During growth, the harvested organs go through $n$ compartments corresponding to increasing physiological ages. The time harvested organs spend in a given compartment is DUREEFRUIT $/ n$. In each compartment, harvested organ growth is equal to the product of the 'sink strength' function FPFT and the source-sink ratio SOURCEPUITS. The FPFT function is the derivative of a logistic function that takes the genetic growth potential of the harvested organ 
into consideration (Bertin \& Gary 1993), the geneticdependent maximal weight of the harvested organ being defined by the parameter PGRAINMAXI.

\section{Carbon pool reserves and remobilization}

Carbon pool reserves are calculated daily as the difference between the total biomass and the accumulated biomass of leaves, stems and harvested organs. They represent the non-structural biomass that can be remobilized. Indeed, reserves built up during the vegetative cycle may be reused later on, the maximal proportion of carbon reserve remobilizable daily being defined by the parameter REMOBRES. This parameter is involved every day in the calculation of the REMOBILJ variable (Eqn 1).

\section{Model adaptation to sugar beet: modelling storage root as a source and sink organ}

The model was first adapted to sugar beet using data from literature and results obtained in sugar beet trials (Launay \& Brisson 2004). The storage root was regarded as a harvested organ and its growth was simulated as described above: it was assumed that harvest occurred before the end of root filling and leaf area growth because the sugar beet cycle is usually interrupted by harvest.

It was also assumed that the carbon pool reserves are located in the storage root, which is able to switch from a sink to a source organ. The storage root dry weight is now the sum of the harvested organ and the carbon pool reserve dry weights. A preliminary calibration stage was necessary to include reserve biomass into the storage root. Because of the close link between LAI and storage root growth through the simulated trophic relationship, parameters for the two processes had to be re-estimated simultaneously. Moreover, the radiation use efficiency parameters determining the potential growth rate of aboveground biomass from intercepted radiation (and thus dependent on the LAI) were re-estimated. Finally, parameters involved in (i) foliar and storage root phenological development and growth, (ii) trophic competition, (iii) remobilization and (iv) radiation use efficiency were estimated by optimization. The Nelder-Mead simplex method (Nelder \& Mead 1965) was implemented on the experimental database including the field trials of Avignon (treatments CI, DI and DE), Mons and Clermont.

\section{Result evaluation}

In order to evaluate the model, two kinds of evaluation criteria were calculated:

1. The mean difference between simulated $\hat{y}_{\mathrm{i}}$ and measured $y_{\mathrm{i}}: \mathrm{MD}=1 / n \sum_{i=1}^{n}\left(\hat{y}_{i}-y_{i}\right)$, where $n$ is the number of replicates. MD indicates the underor over-estimate.
2. The relative root mean square error (RRMSE): $\operatorname{RRMSE}=1 / \bar{y}\left(1 / n \sum\left(y_{i}-\hat{y}_{i}\right)^{2}\right)^{1 / 2}$, where $\bar{y}$ is the average of observed values $y_{\mathrm{i}}$.

Further analyses of variance were carried out, using the AOV procedure of the S-PLUS software (S-PLUS 2001). The significance of differences between treatments was estimated using $F$-tests at $P<0 \cdot 05$, and the means were compared using the Student $t$ test at $P<0.05$.

\section{RESULTS}

\section{Sugar beet behaviour in the field experiments}

\section{Leaf re-growth after stress release}

The trials were done in various water conditions both in terms of soil moisture dynamics and atmospheric demand. These situations led to water stress, as indicated by a decreasing LAI, of varying extent: LAI losses of 1.0 in Clermont (Fig. $3 a$ ) and 3.0 in Mons and Avignon DI (Fig. 3b,d), corresponding to a $200 \mathrm{~mm}$ decrease in soil moisture. In Avignon CI (Fig. 3c), two periods of about $100 \mathrm{~mm}$ water depletion resulted in LAI losses of 1.0 and $1 \cdot 5$. Conversely, soil re-hydration periods following rainfall or irrigation allowed leaf re-growth: in Clermont and Mons (Fig. $3 a, b$ ), rainfalls of 37 and $68 \mathrm{~mm}$ provoked LAI increases of about 1 and 0.5 LAI units, respectively. In Avignon CI, the two periods of soil water increase were associated with LAI increases of 1.0 and 0.5 . A similar increase was observed after the second irrigation in Avignon DI; the first irrigation interrupted the LAI decrease temporarily. In some cases the two processes were not concomitant; the LAI regrowth was later than the soil recharge. Moreover, in the Avignon trial, the last measurements were made on 13 December $2005,3800{ }^{\circ} \mathrm{Cdae}$, and green leaf biomass was between 243 and $440 \mathrm{~g} / \mathrm{m}^{2}$ depending on the treatment.

Figure 4 shows changes in SLA, which parallel the changes in LAI during the onset of drought. After the stress release, the increase in LAI was generally independent of SLA dynamics. Indeed in treatments CI and DI at Avignon, SLA remained constant or decreased during LAI regrowth, except in CI during the second period of soil water recharge (Fig. 4c). However, in this case and in Clermont and Mons (Fig. $4 a, b$ ), brief small SLA increases occurred, but they were not significant at $P<0 \cdot 05$. Moreover, in all field trials, LAI increases were invariably linked to leaf dry matter increases (data not shown), refuting the possibility that the LAI re-growth was due to SLA increase. Finally, in the Avignon treatment CI where a 1.0 LAI unit increase was measured (Fig. 4c), an estimate was made of the potential assimilates formed during these 4 days. The solar radiation intercepted by the crop during this period was 

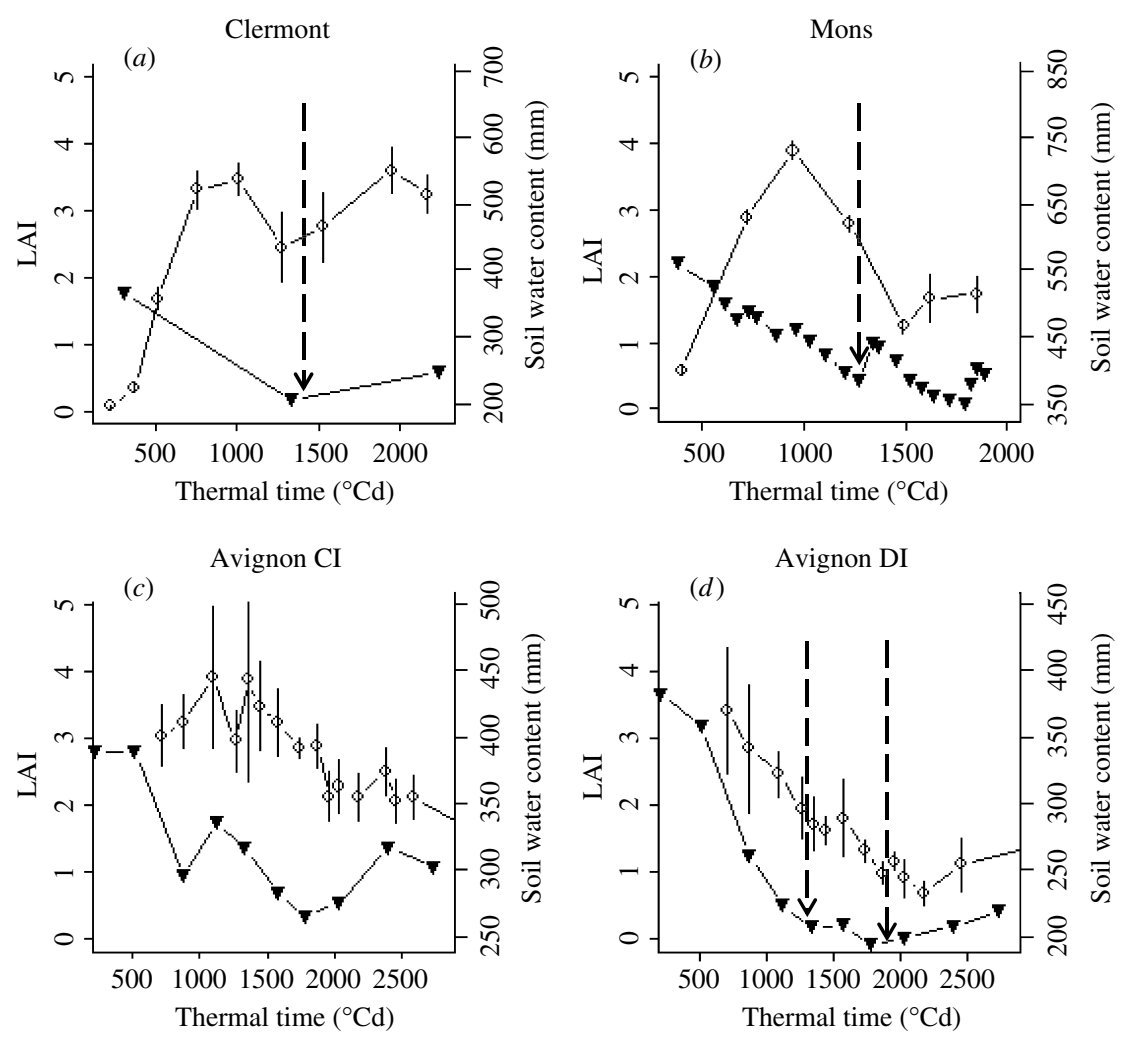

Fig. 3. Measured LAI $(\bigcirc)$ and soil water content $(\mathrm{mm})(\boldsymbol{\nabla})$ in $(a)$ Clermont, $(b)$ Mons, $(c)$ Avignon treatment CI (continuous irrigation) and (d) Avignon treatment DI (discontinuous irrigation). Soil water content was measured in the $0-1 \cdot 2 \mathrm{~m} \mathrm{soil} \mathrm{layer}$ in Avignon and Clermont, and in the $0-1.8 \mathrm{~m}$ soil layer in Mons. Values are means \pm s.E. Arrows indicate major summer rainfalls in Clermont and Mons and irrigation resumptions in Avignon DI.

calculated by interpolating LAI linearly between the two measurement dates, and using the following equation (Eqn (2)):

$$
\operatorname{Rgi}=\operatorname{Rgo}\left(1-\mathrm{e}^{(-k \mathrm{LAI})}\right)
$$

where Rgi is the solar radiation intercepted by the crop, Rgo is the global radiation and $k$ is the radiation interception coefficient, equal to 0.53 for sugar beet (Varlet-Grancher et al. 1989).

Assuming a high radiation use efficiency of $1.8 \mathrm{~g} / \mathrm{MJ}$ (Scott \& Jaggard 1993), the potential biomass production during this period was estimated at about $170 \mathrm{~g} / \mathrm{m}^{2}$, which may not offset the measured leaf biomass production of $116 \mathrm{~g} / \mathrm{m}^{2}$. If it is assumed that the proportion of assimilates allocated to the shoot is at most 0.5 (Webb et al. 1997), then the new dry matter is not sufficient to account for the $116 \mathrm{~g} / \mathrm{m}^{2}$ increase in the leaf dry weight.

Finally, there was no decrease in storage root dry weight (Fig. 4) at Clermont, Mons and Avignon DI, whereas two periods of about $0.5 \times 10^{3} \mathrm{~g} / \mathrm{m}^{2}$ root biomass loss (significant at $P<0.05$ ) appeared in Avignon CI (Fig. 4c), those periods being not exactly concomitant with LAI re-growth.

Leaf regrowth and sugar content decrease in storage roots after defoliation

After total defoliation in Avignon treatment DE at $2200{ }^{\circ} \mathrm{Cdae}$, leaves suddenly grew again, LAI recovering to $0 \cdot 25$ in about $350{ }^{\circ} \mathrm{Cd}$ (Fig. $5 b$ ), which corresponds to a growth rate of $0.06 \mathrm{~g} / \mathrm{m}^{2} /{ }^{\circ} \mathrm{C}$. Just after defoliation, sugar beet plants produced new leaves with large laminae and short petioles, representing 0.86 and 0.14 , respectively, of the total green leaf dry weight (measurements made $400{ }^{\circ} \mathrm{Cd}$ after defoliation). However, in the late autumn $\left(3800^{\circ} \mathrm{Cdae}\right)$, green leaf dry weight was mostly attributable to large petioles, whose weight represented 0.90 of the total green leaf dry weight.

A simultaneous decrease in sugar content was measured in storage roots of treatment DE, from comprising 0.33 to 0.30 of the storage root dry 
(a)

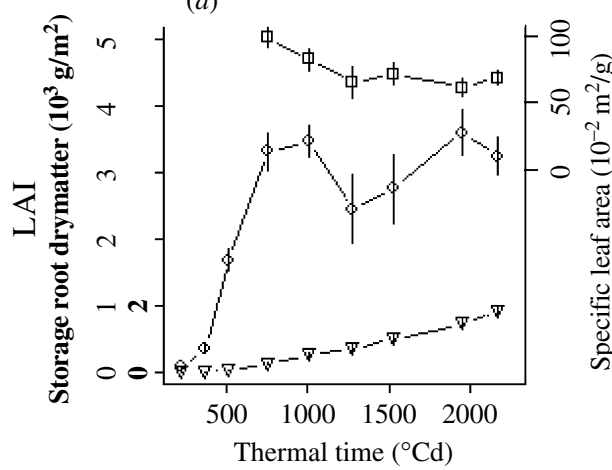

Avignon CI

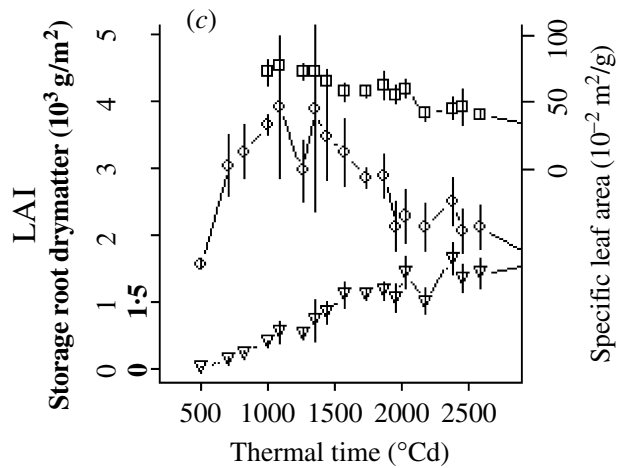

Mons

(b)

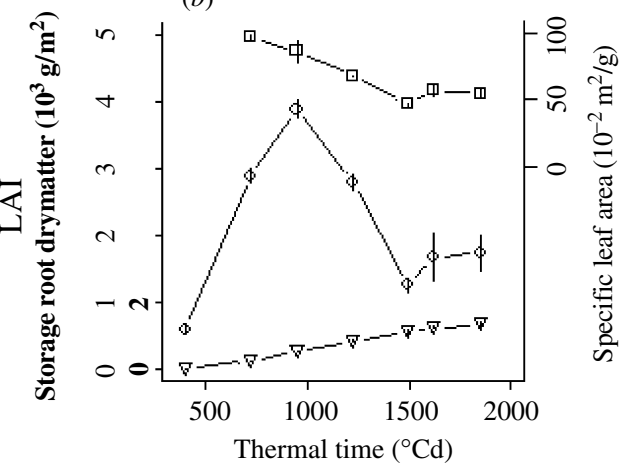

Avignon DI

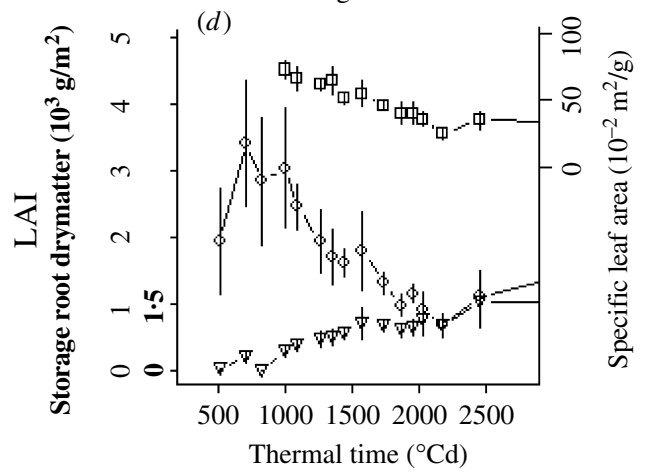

Fig. 4. Measured LAI $(\bigcirc)$, specific leaf area (SLA; $\left.10^{-2} \mathrm{~m}^{2} / \mathrm{g}\right)(\square)$ and storage root dry weight $\left(10^{3} \mathrm{~g} / \mathrm{m}^{2}\right)(\boldsymbol{\nabla})$ in (a) Clermont, (b) Mons, (c) Avignon treatment CI and $(d)$ Avignon treatment DI. Values are means \pm S.E.

Avignon CI

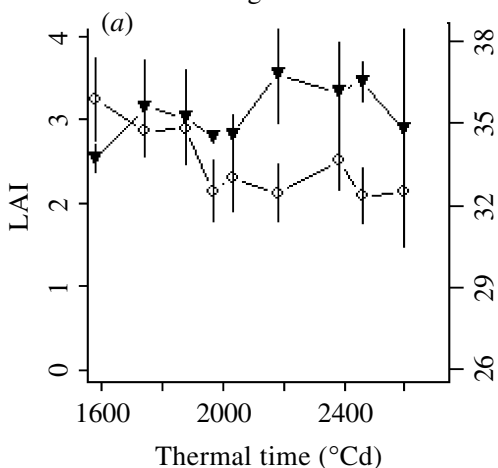

Avignon DE

(b)

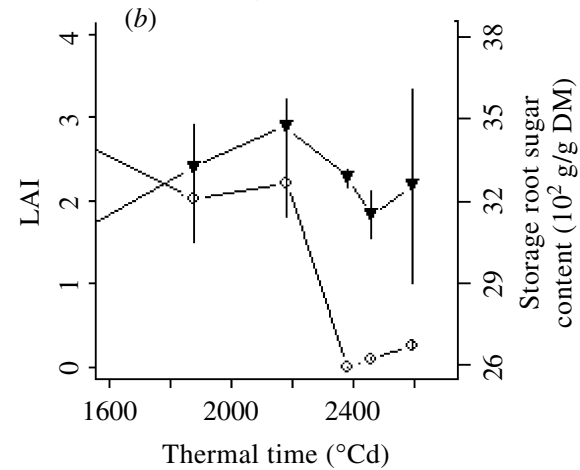

Fig. 5. Measured LAI $(\bigcirc)$ and sugar content in storage root $\left(10^{2} \mathrm{~g} / \mathrm{g}\right.$ of storage root dry matter $)(\boldsymbol{\nabla})$ in $(a)$ Avignon treatment $\mathrm{CI}$ and $(b)$ Avignon treatment DE (defoliated). Values are means \pm s.E.

weight in $240{ }^{\circ} \mathrm{Cd}$ (Fig. 5 b). Sugar contents of storage roots were significantly different before and after defoliation in treatment $\mathrm{DE}$, while there was no difference in the non-defoliated treatment CI (Fig. $5 a$ and Table 2). Before defoliation, sugar contents were similar in treatments $\mathrm{CI}$ and $\mathrm{DE}(P=0 \cdot 17)$. 
Table 2. Sugar content in storage roots, before and after defoliation, in treatment CI and DE at Avignon

\begin{tabular}{llccc}
\hline \hline \multirow{5}{*}{ Treatment } & \multicolumn{3}{c}{$\begin{array}{c}\text { Sugar content } \\
(\mathrm{g} / \mathrm{g} \text { dry weight of storage root })\end{array}$} \\
\cline { 3 - 5 } & & $\begin{array}{c}\text { Before } \\
\text { defoliation }\end{array}$ & After defoliation \\
\hline & Thermal time after emergence $\left({ }^{\circ} \mathrm{Cd}\right)$ & 2180 & 2380 & 2460 \\
& CI & 0.35 & $0 \cdot 34$ & $0 \cdot 34$ \\
& Significance of difference from before defoliation & & 0.67 & $0 \cdot 81$ \\
& DE (defoliated) & $0 \cdot 31$ & $0 \cdot 30$ \\
& Significance of difference from before defoliation & & $0 \cdot 04$ & $0 \cdot 01$ \\
\hline \hline
\end{tabular}

\section{LAI}

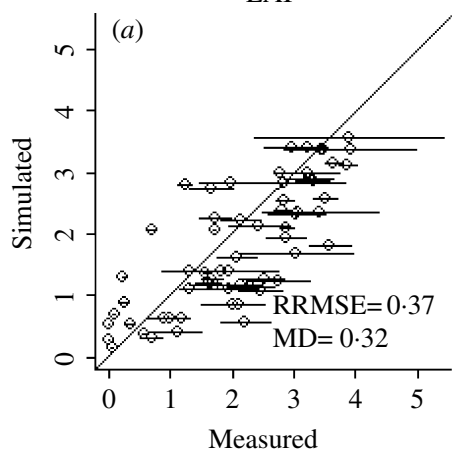

Total aboveground dry matter $\left(10^{3} \mathrm{~g} / \mathrm{m}^{2}\right)$

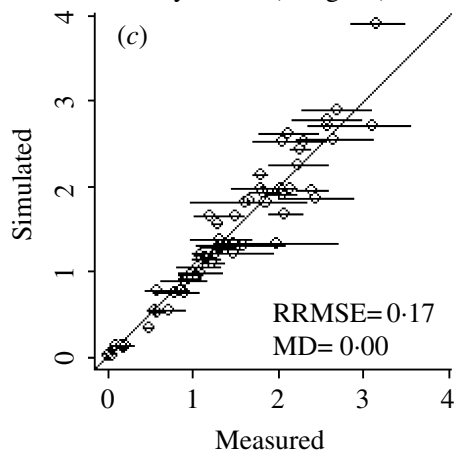

Soil water content in the soil profile $(\mathrm{mm})$

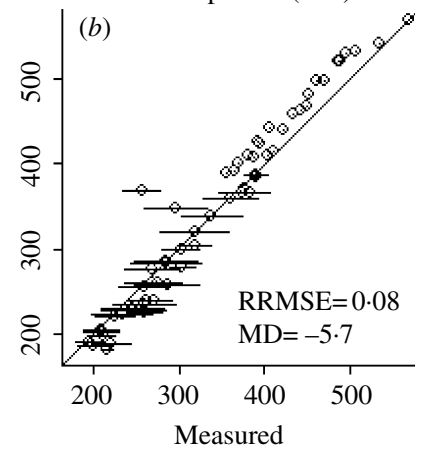

\section{Storage root} dry matter $\left(10^{3} \mathrm{~g} / \mathrm{m}^{2}\right)$

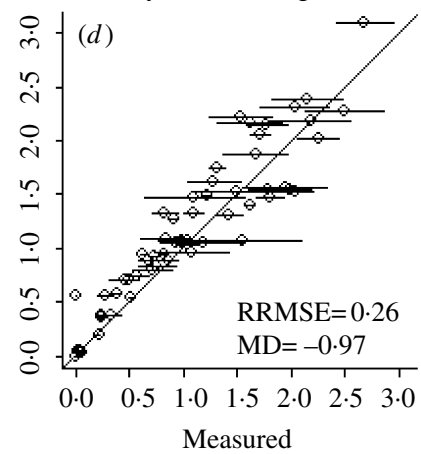

Fig. 6. Evaluation of the model by comparing observed and simulated (a) LAI, $(b)$ soil water content in the soil profile (mm), (c) total above-ground dry matter $\left(10^{3} \mathrm{~g} / \mathrm{m}^{2}\right)$ and $(d)$ storage root dry weight $\left(10^{3} \mathrm{~g} / \mathrm{m}^{2}\right)$. Values are means \pm s.E. ( $(-\operatorname{line} 1: 1)$. Respective RRMSE and MD are given.

\section{Remobilization assumption tested through an heuristic modelling approach}

Other evidence was sought for the role played by remobilization in sugar beet through the STICS crop model formalizations.
Key variables indicating the model's ability to simulate partitioning and translocation of biomass in source and sink organs (LAI, above-ground and storage root dry weights), as well as to reproduce the source of drought stress (i.e. soil water content), are presented in Fig. 6 together with the observed values. 

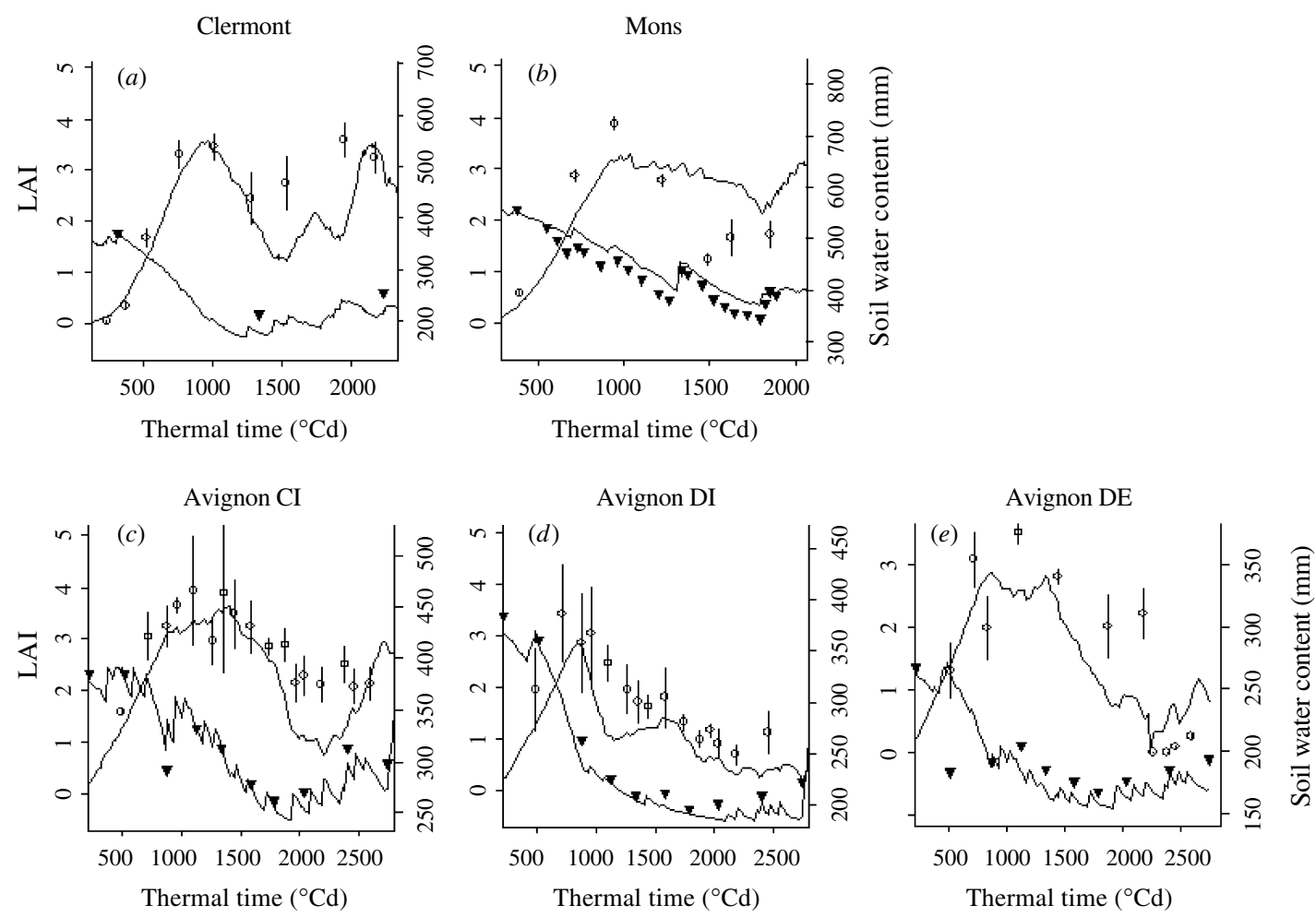

Fig. 7. Daily simulated LAI and soil water contents $(\mathrm{mm})$, and LAI and soil water content measurements in (a) Clermont, $(b)$ Mons and $(c-e)$ Avignon trials. Measured values are means \pm S.E.

Simulated LAIs were under-estimated by the model with a mean deviation (MD) of about 0.32 (Fig. 6a), whereas soil water content (Fig. 6b) and total aboveground biomass (Fig. 6c) were estimated without bias $\left(\mathrm{MD}=-5.7 \mathrm{~mm}\right.$ and $0.003 \times 10^{3} \mathrm{~g} / \mathrm{m}^{2}$, respectively) and good accuracy (RRMSE $=0.08$ and $0 \cdot 17$, respectively). However, the slight over-estimation of soil water content in wet conditions (more than $400 \mathrm{~mm}$ in the whole soil profile) could be attributed to the under-estimation of LAI, especially at Mons for LAI values of 3-4 (Fig. 7b), in turn leading to an under-estimation of plant transpiration. The storage root dry weight (Fig. 6d) was estimated with no bias $(\mathrm{MD}=-0.97)$ but considerable scatter $(\mathrm{RRMSE}=$ $0 \cdot 26)$ and the measurements were noticeably variable.

LAI values were reproduced by the model, especially the leaf regrowth when drought stress ceased in Clermont at $1500{ }^{\circ} \mathrm{Cdae}$ (Fig. $7 a$ ), in Avignon CI around $2200^{\circ}$ Cdae (Fig. $7 c$ ), in Avignon CI around $1300^{\circ} \mathrm{Cdae}$ (Fig. $7 d$ ), or after defoliation at $2300^{\circ}$ Cdae for Avignon DE (Fig. 7e). In Mons (Fig. $7 b$ ), the LAI decrease and subsequent increase from 1000 to $2000{ }^{\circ} \mathrm{Cdae}$ was not reproduced in terms of the range of values, but the soil re-wetting at $1800{ }^{\circ} \mathrm{Cdae}$ induced a clear leaf regrowth. In Avignon
DI (Fig. $7 d$ ), the model also failed to reproduce leaf regrowth after the second irrigation at $1900{ }^{\circ} \mathrm{Cdae}$, which seemed to be linked with the poor simulation of the soil rehydration on this date. Moreover, LAI was particularly under-estimated when drought stress occurred during the second half of the crop cycle in Clermont (Fig. 6a) and Avignon CI (Fig. 6c), and throughout crop growth in Avignon DI (Fig. 6d).

The re-estimation of model parameters, regarding the storage root as a carbon reservoir, led to the following values: the phenological parameters driving leaf and storage root growth durations were estimated at about $6000{ }^{\circ} \mathrm{Cdae}$ from emergence to the end of leaf growth and at about $11000{ }^{\circ} \mathrm{Cdae}$ from emergence to the end of storage root filling; the PGRAINMAXI parameter, corresponding to the genetic-dependent maximal weight of the harvested organ, was estimated at $1060 \mathrm{~g}$; the trophic stress parameters SPLAIMIN and SPLAIMAX were estimated at -0.84 and 1.06 , respectively; the maximal proportion of carbon reserve remobilizable daily (REMOBRES parameter) was estimated to represent $0 \cdot 30$ of the total carbon pool reserves.

Finally, the model allowed quantification of the remobilized amounts of storage dry matter. As shown 

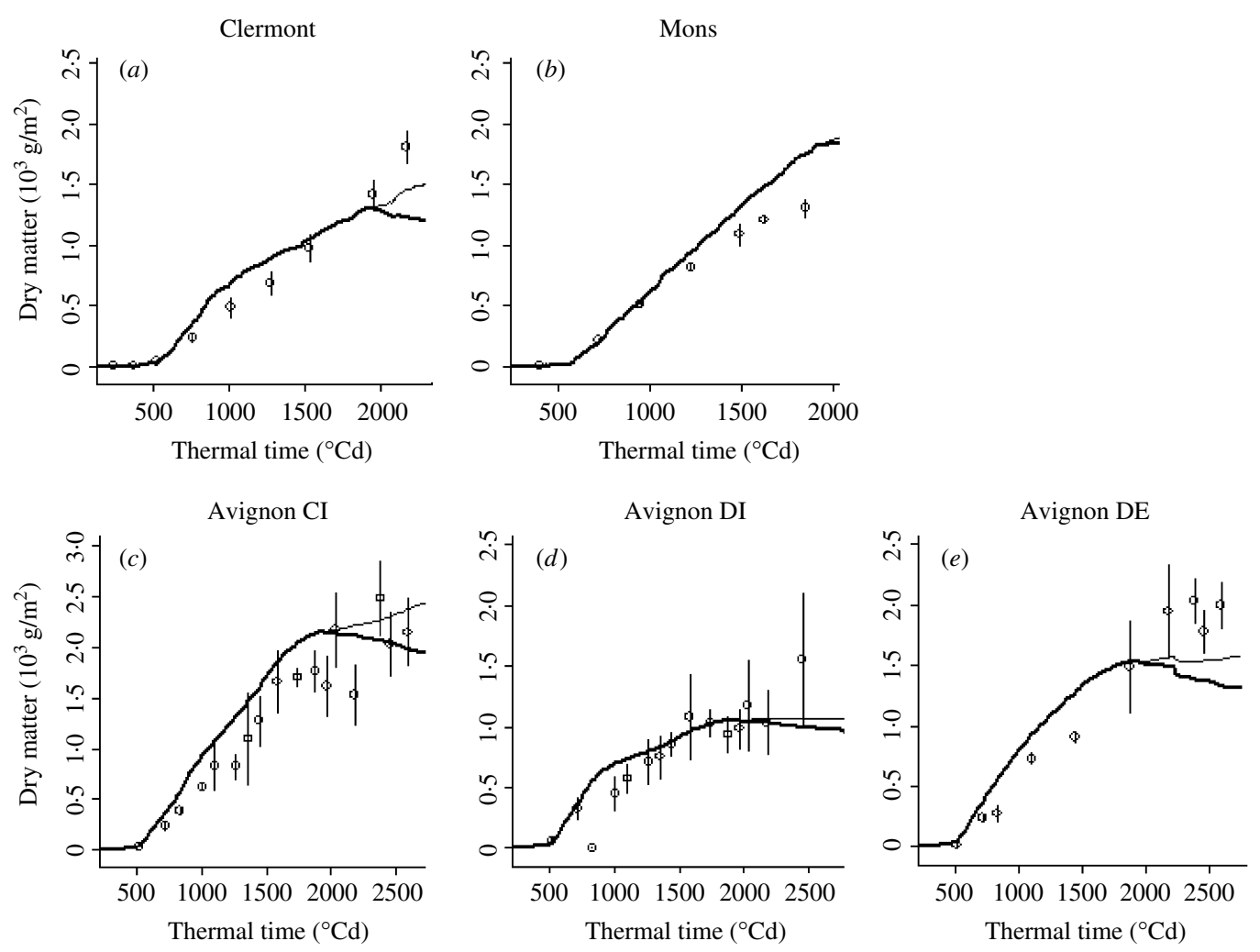

Fig. 8. Measured $(\bigcirc)$ and daily simulated $(-)$ storage root dry weight $\left(10^{3} \mathrm{~g} / \mathrm{m}^{2}\right)$, and simulated $(-)$ carbon pool reserve dry weight $\left(10^{3} \mathrm{~g} / \mathrm{m}^{2}\right)$ in $(a)$ Clermont, $(b)$ Mons and $(c-e)$ Avignon trials. Measured values of storage root dry weights are means \pm S.E.

in Fig. 8, the simulated total storage root dry weight was similar to the measurements. The model simulated the carbon pool reserve as the majority of storage root dry weight. During the drought in summer, this simulated pool decreased because of remobilization, but the total storage root dry matter kept on increasing. In the Avignon DE trial (Fig. 8e), throughout the 10 days after defoliation, the simulated remobilized dry weight was $0 \cdot 1210^{3} \mathrm{~g} / \mathrm{m}^{2}$, which represented around 0.08 of the total storage root dry weight and nearly 0.70 of the new leaf dry weight. In other trials, simulated carbon pool reserves represented from $0 \cdot 50$ (Avignon) to 0.80 (Mons) of the total storage root dry weight, and accumulated remobilized dry matter was simulated from 0.06 (Mons) to 0.30 (Avignon DI) of the final storage root dry weight.

\section{DISCUSSION}

The objective of the present paper was to demonstrate, with experimental and modelling approaches, the ability of sugar beet to remobilize carbohydrates from its storage root to support leaf regrowth after stress release. In the field trials, leaf regrowth was observed after drought stress was relieved. This ability of sugar beet has already been described by Owen \& Watson (1956) and Milford et al. (1985). The primary explanation is of a botanical nature: the sugar beet crop is cultivated during its vegetative phase only, i.e. no ontogenic signal prevents leaves from growing during this period (Perata et al. 2004). Milford et al. (1985) showed, on a series of distinct sugar-beet crops grown during five consecutive seasons, that a linear relationship could be fitted between leaf number and thermal time until $2000{ }^{\circ} \mathrm{C}$ after sowing, with no plateau, suggesting that it could increase at the same rate for longer. This result was confirmed in the present work by the last measurements made in December in the Avignon trial, illustrating sugar beet's ability to produce new leaves throughout its life. Secondly, as previously shown that leaf regrowth could not be explained by SLA increase or resumption of photosynthetic activity, this leaf renewal property must rely on the possibility of remobilizing stored resources to support this 
energy-consuming activity. However, the measurements in field trials in the present work were not relevant to accurately quantify the remobilization process and could not reveal storage root dry weight decrease, together with LAI regrowth after stress release. However, a defoliation treatment demonstrated the simultaneous leaf regrowth and sugar content decrease in storage roots after defoliation, showing that storage roots can be sources as well as sinks. This phenomenon occurs not only in a phenological timedependent way (sinks during the vegetative stage and sources during the reproductive stage), but also even during the vegetative stage, the switch between source and sink being triggered by environmental stress. This property, shown in the present work by an artificial stress induced by defoliation, may explain sugar beet's plasticity to cope with drought. It brings the sugar beet crop closer to perennial ones, thanks to this functional similarity. Like grassland ecosystems (Volenec et al. 1996; Frankow-Lindberg 2001) or woody plants (Sakai \& Sakai 1998; Teng et al. 1999; Wong et al. 2003; Cheng et al. 2004), sugar beet is able to accumulate and subsequently use carbohydrates to supply biomass and energy for re-growth. This is of particular importance in the case of sugar beet because the source/sink organ is the harvested one, and indeed a balance should be maintained in relation to environmental conditions in order to maximize yield.

The experimental approach, designed in order to reveal remobilization, was supplemented by a heuristic use of the crop model STICS to validate the assumption of this process. Two main results indicated that the model could simulate sugar beet's capacity for remobilization fairly well and therefore confirmed the hypothesis: first, the model's ability to simulate the output variables involved in sugar beet remobilization and second, the re-estimation of model parameters when treating the storage root as a carbon pool, which led to establish a single set of parameters.

First, the agreement between measurement and simulated trends in LAI and soil water content, and especially the reproduction of leaf regrowth when drought stress ceased, supported the model's ability to simulate remobilization. However, the underestimation of LAI when drought stress occurred brought out the model's limitations. As the soil moisture was correctly simulated for these trials, it can be assumed that the effect of drought stress on LAI growth was over-estimated, as noticed previously (Launay \& Brisson 2004). Thus, although the LAI simulation has already been improved by taking remobilization into account, its accuracy should now be increased, especially when daily variations are important. This may be particularly interesting when coupling a crop model with remote sensing data (Baret et al. 2007). Moreover, it can help when attempting to simulate foliar re-growth after pest damage, when pests either consume leaf tissue or accelerate abscission (Boote et al. 1983).

Secondly, re-estimation of model parameters led to similar sets of physiologically meaningful parameter values. The single solution values obtained in this way demonstrated the value of the model to simulate leaf dynamics in these trials. The estimated values of the phenological parameters driving leaf and storage root growth durations were large, which is consistent with sugar beet's biennial cycle and its ability to extend storage root growth and to maintain leaf cover during the first year. The estimated value of the genetic-dependent parameter corresponding to the maximal weight of the harvested organ was in accord with this phenological duration of storage root growth. The trophic stress parameter values expressed the smaller effect of trophic competition on leaf actual growth than on storage root potential growth. They were relevant to the need to simulate leaf regrowth during a drought stress release, but could penalize storage root growth rate at other times.

Finally, the simulation results of carbon pool reserves were comparable to the measurements of Lawson et al. (2000) on white clover cultivars, which showed that the combined utilization of starch and water-soluble carbohydrate reserves in the first 14 days after defoliation was equivalent to $0 \cdot 15$ of the plant weight at defoliation, and to 0.95 of the new leaf produced during that period. However, the structural part of the simulated total storage root dry weight was obviously under-estimated. Ecophysiological approaches in controlled conditions, possibly supplemented by isotopic tracing, would allow structural and non-structural parts of the storage root to be distinguished, remobilized amounts to be measured, and the contribution of remobilized carbohydrates to leaf regrowth to be estimated. This approach could rely on the previous study by Monti et al. (2006), who determined carbon isotope discrimination on soluble sugars and bulk dry matter of different parts of sugar beet biomass. Similar studies have been attempted on other species for which the harvested organ was not the source organ, and led to very differing results: Royo et al. (1999) measured contributions of preanthesis reserves to triticale grain yield ranging from 0.18 to 0.67 of grain dry weight, whereas Subbarao et al. (2000) showed that the contribution of nonstructural carbohydrates from stem reserves to pigeon pea grain yield under water deficit conditions never exceeded 0.05 of grain yield. Indeed, as remobilization contributions to harvested organ dry weight may be very different according to species, sugar beet could be taken as a plant model to study remobilization in species for which the harvested organ is a sink as well as a source. However, the focus in the present study was on drought stress. Further agronomic studies are now needed to define the 
environmental and internal factors limiting the sugar beet remobilization process.

The model's generality was a great asset in the present study, since relationships already introduced for other species proved to be relevant for sugar beet, showing the functional similarity between species that are very different botanically. Moreover, the simulation results showed the robustness of the model to forecast sugar beet biomass production, especially when drought stress occurs during summer and then is released in autumn. Lastly, the agronomic experiments and the modelling approach both provided a strong hypothesis that should be now tested with ecophysiological experiments and molecular methods.

We gratefully acknowledge the technical support of the INRA staff at the experimental farms of INRALaon and INRA-Avignon. We thank M. Lejealle from Deleplanque Compagny for providing seeds and technical support in the Avignon trial. This programme received funding from the Institut Technique de la Betterave Industrielle.

\section{REFERENCES}

Asseng, S. \& Van Herwaarden, A. F. (2003). Analysis of the benefits to wheat yield from assimilates stored prior to grain filling in a range of environments. Plant and Soil 256, 217-229.

Baret, F., Houlès, V. \& Guérif, M. (2007). Quantification of plant stress using remote sensing observations and crop models: the case of nitrogen management. Journal of Experimental Botany 58, 869-880.

Bertin, N. \& GARY, C. (1993). Evaluation of TOMGRO, a dynamic model of growth and development of tomato (Lycospersicon esculentum Mill) at various levels of assimilate supply and demand. Agronomie 13, 395-405.

Boote, K. J., Jones, J. W., Mishoe, J. W. \& Berger, R. D. (1983). Coupling pests to crop growth simulators to predict yield reductions. Phytopathology 73, 1581-1587.

Brisson, N., Gary, C., Justes, E., Roche, R., Mary, B., Ripoche, D., Zimmer, D., Sierra, J., Bertuzzi, P., Burger, P., Bussiere, F., Cabidoche, Y. M., Cellier, P., Debaeke, P., Gaudillere, J. P., Henault, C., Maraux, F., Seguin, B. \& Sinoquet, H. (2003). An overview of the crop model STICS. European Journal of Agronomy 18, 309-332.

Brisson, N., Launay, M., Mary, B. \& Beaudoin, N. (2009). Conceptual Basis, Formalisations and Parameterization of the STICS Crop Model. Paris: QUAE.

Ceotto, E., Guérif, M. \& Duke, C. L. (1999). Evaluation of the model SUCROS2 for simulating sugar beet growth and production in water limited conditions in Northern France. In Modelling Cropping Systems: Proceedings of an International Symposium, 21-23 June 1999, Lleida, Spain (Eds M. Donatelli, C. Stockle, F. Villalobos \& J. M. Villar Mir), pp. 157-158. Thiverval Grignon, France: ESA.

Cheng, L. L., XiA, G. H. \& Bates, T. (2004). Growth and fruiting of young 'Concord' grapevines in relation to reserve nitrogen and carbohydrates. Journal of the American Society for Horticultural Science 129, 660-666.

Dordas, C. A. \& Sioulas, C. (2009). Dry matter and nitrogen accumulation, partitioning, and retranslocation in safflower (Carthamus tinctorius L.) as affected by nitrogen fertilization. Field Crops Research 110, 35-43.

EвrAhim, M. K. H. (2005). Amelioration of sucrosemetabolism and yield changes, in storage roots of NaClstressed sugarbeet, by ascorbic acid. Agrochimica 49, 93-103.

El Omari, B., Aranda, X., Verdaguer, D., Pascual, G. \& FLECK, I. (2003). Resource remobilization in Quercus ilex L. resprouts. Plant and Soil 252, 349-357.
FAO. (2006). World Reference Base for Soil Resources. A Framework for International Classification, Correlation and Communication. Rome, Italy: FAO. Available online at: http://www.fao.org/ag/agl/agll/wrb/doc/ wrb2006final.pdf (verified 2 June 2009).

Frankow-LindBerG, B. E. (2001). Adaptation to winter stress in nine white clover populations: changes in nonstructural carbohydrates during exposure to simulated winter conditions and 'spring' regrowth potential. Annals of Botany 88, 745-751.

Gordon, A. J., Ryle, G. J. A., Mitchell, D. F., Lowry, K. H. \& Powell, C. E. (1986). Effects of defoliation on carbohydrate, protein and leghaemoglobin content of white clover nodules. Annals of Botany 58, 141-154.

Guérif, M., Machet, J. M. \& Droulin, J. F. (1995). Utilisation de la télédétection pour caractériser le statut azoté des cultures de betteraves sucrières. In Proceedings of the 58th International Institute for Beet Research Congress, 20 June 1995, Beaune, France, pp. 551-556. Brussels, Belgium: IIRB.

LAunAY, M. \& BRISSON, N. (2004). STICS adaptability to a novel crop as an application of modularity in crop modelling: example of sugar beet. In VIII ESA Congress: European Agriculture in a Global Context (Eds S. E. Jacobsen, C. R. Jensen \& J. R. Porter), pp. 283-286. Copenhagen, Denmark: ESA.

Launay, M. \& Guerif, M. (2003). Ability for a model to predict crop production variability at the regional scale: an evaluation for sugar beet. Agronomie 23, 135-146.

Lawson, A. R., Kelly, K. B. \& Sale, P. W. G. (2000). Defoliation frequency and cultivar effects on the storage and utilisation of stolon and root reserves in white clover. Australian Journal of Agricultural Research 51, 10391046.

Lemaire, G. \& Meynard, J. M. (1997). Use of the nitrogen nutrition index for the analysis of agronomical data. In Diagnosis of the Nitrogen Status in Crops (Ed. G. Lemaire), pp. 45-55. Heidelberg, Germany: SpringlerVerlag.

McCown, R. L., Hammer, G. L., Hargreaves, J. N. G., Holzworth, D. P. \& Freebairn, D. M. (1996). APSiM: a novel software system for model development, model testing, and simulation in agricultural systems research. Agricultural Systems 50, 255-271.

Milford, G. F. J., Pocock, T. O. \& Riley, J. (1985). An analysis of leaf growth in sugar beet. II. Leaf appearance in field crops. Annals of Applied Biology 106, $173-185$. 
Monti, A., Brugnoli, E., Scartazza, A. \& Amaducci, M. T. (2006). The effect of transient and continuous drought on yield, photosynthesis and carbon isotope discrimination in sugar beet (Beta vulgaris L.). Journal of Experimental Botany 57, 1253-1262.

Nelder, J. A. \& Mead, R. (1965). A simplex method for function minimization. The Computer Journal 7, 308-313.

Owen, P. C. \& WATSON, D. J. (1956). Effect on crop growth of rain after prolonged drought. Nature 177, 847.

Papakosta, D. K. \& Gagianas, A. A. (1991). Nitrogen and dry matter accumulation, remobilization, and losses for Mediterranean wheat during grain filling. Agronomy Journal 83, 864-870.

Perata, P., Poggiolini, S., Poggi, A., Meriggi, P. \& Ribeyre, C. (2004). Accumulation of sucrose in roots related to beet canopy growth in the Po Valley (NorthEast Italy). In 67th IIRB Congress, 11-12 February 2004, Brussels, Belgium. pp. 75-82. Brussels, Belgium: IIRB.

Probert, M. E., Keating, B. A., Thompson, J. P. \& Parton, W. J. (1995). Modelling water, nitrogen, and crop yield for a long-term fallow management experiment. Australian Journal of Experimental Agriculture 35, 941-950.

Rossi, A., Meriggi, P., Biancardi, E. \& Rosso, F. (2000). Effect of Cercospora leaf spot on sugar beet growth, yield and quality. In Proceedings of the 63rd IIRB Congress, 9-10 February 2000, Interlaken, Switzerland, pp. 49-76. Brussels, Belgium: IIRB.

Royo, C., Voltas, J. \& Romagosa, I. (1999). Remobilization of pre-anthesis assimilates to the grain for grain only and dual-purpose (forage and grain) triticale. Agronomy Journal 91, 312-316.

Rubino, P., Cantore, V. \& Mastro, M. A. (1999). Study of water use efficiency of some herbaceous species in an area of southern Italy. Rivista di Irrigazione e Drenagio 46, $39-46$.

SAKAI, A. \& SAKAI, S. (1998). A test for the resource remobilization hypothesis: Tree sprouting using carbohydrates from above-ground parts. Annals of Botany 82, 213-216.

Schapendonk, A. H. C. M., Stol, W., Van KraAlingen, D. W. G. \& Bouman, B. A. M. (1998). LINGRA, a sink/ source model to simulate grassland productivity in Europe. European Journal of Agronomy 9, 87-100.

Scott, R. K. \& JAGGard, K. W. (1993). An analysis of the efficiency of the sugar beet crop in exploiting the environment. Journal of Sugar Beet Research 30, 37-56.

Smit, A. B. \& Struik, P. C. (1995). The first step towards a decision-support system for sugar beet growing: selection of a basic growth model. Journal of Agronomy and Crop Science 175, 213-220.
Spitters, C. J. T. \& Schapendonk, A. H. C. M. (1990). Evaluation of breeding strategies for drought tolerance in potato by means of crop growth simulation. Plant and Soil 123, 193-203.

Spitters, C. J. T., Van Keulen, H. \& Van Kraalingen, D. W. G. (1989). A simple and universal crop growth simulator: SUCROS87. In Simulation and System Management in Crop Protection (Eds R. Rabbinge, S. A. Ward \& H. H. van Laar), pp. 147-181. Simulation Monographs 32. Wageningen: Pudoc.

S-Plus (2001). S-PLUS 6 for Windows, Guide to Statistics. Vol. 1. Seattle, WA: Insightful Corporation.

Subbarao, G. V., Nam, N. H., Chauhan, Y. S. \& Johansen, C. (2000). Osmotic adjustment, water relations and carbohydrate remobilization in pigeonpea under water deficits. Journal of Plant Physiology 157, 651-659.

TAhiR, I. S. A., Nakata, N. \& Yamaguchi, T. (2005). Responses of three wheat genotypes to high soil temperature during grain filling. Plant Production Science $\mathbf{8}$, 192-198.

Teng, Y. W., Tanabe, K., Tamura, F. \& Itai, A. (1999). Translocation of C-13-assimilates in the spring following fall assimilation of (CO2)-C-13 by 'Nijisseiki' pear (Pyrus pyrifolia Nakai). Journal of the Japanese Society for Horticultural Science 68, 248-255.

Varlet-Grancher, C., Gosse, G., Chartier, M., Sinoquet, H., Bonhomme, R. \& Allirand, J.-M. (1989). Mise au point: rayonnement solaire absorbé ou intercepté par un couvert végétal. Agronomie 9, 419-439.

Vizoso, S., Gerant, D., Guehl, J. M., Joffre, R., Chalot, M., Gross, P. \& Maillard, P. (2008). Do elevation of $\mathrm{CO}_{2}$ concentration and nitrogen fertilization alter storage and remobilization of carbon and nitrogen in pedunculate oak saplings? Tree Physiology 28, 17291739.

Volenec, J. J., Ourry, A. \& Joern, B. C. (1996). A role for nitrogen reserves in forage regrowth and stress tolerance. Physiological Plantarum 97, 185-193.

Webb, C. R., Werker, A. R. \& Gilligan, C. A. (1997). Modelling the dynamical components of the sugar beet crop. Annals of Botany 80, 427-436.

Wong, B. L., Baggett, K. L. \& Rye, A. H. (2003). Seasonal patterns of reserve and soluble carbohydrates in mature sugar maple (Acer saccharum). Canadian Journal of Botany-Revue Canadienne De Botanique 81, 780-788.

YANG, J. C., Zhang, J. H., WANG, Z. Q., ZhU, Q. S. \& LiU, L. J. (2004). Activities of fructan- and sucrose-metabolizing enzymes in wheat stems subjected to water stress during grain filling. Planta 220, 331-343. 